\title{
A NEW SPECIES MEGALOMOIDEA WALLISERI (BIVALVIA) FROM THE SILURIAN OF ESTONIA
}

\author{
Mare ISAKAR a and Irina SINICYNA
}

a Tartu Ulikool (Tartu University). Vanemuise 46, EE-2400 Tartu, Eesti (Estonia)

b Санкт-Петербургский университет (St. Petersburg University). 16 линия 29, 199106 Санкт-Петербург, Россия (Russia)

Presented by D. Kaljo

Received December 24, 1992; accepted March 23, 1993

Abstract. A new species Megalomoidea walliseri from the Kogula quarry (Ludlow) is described. Characteristic of the new species is presence of a large, relatively thin shell with four cardinal teeth and deeply impressed muscular scars.

Key words: Bivalvia, Megalomoidea, Silurian, Estonia.

In August 1990, during the field excursion of the Ordovician and Silurian subcommissions to Saaremaa Island, Prof. Otto $\mathrm{H}$. Walliser found a shell of a bivalve. It was a large left valve with a well preserved hinge and impressions of muscular scars. This made it possible to describe this specimen as a new species of the genus Megalomoidea. Cox. The species name is given in honour of the finder.

This shell was found at the new Kogula quarry on Saaremaa Island where the middle part of the Sauvere Beds of the Paadla Stage is exposed. According to personal information of $\mathrm{R}$. Einasto the holotype of the new species originates from a layer of wavy-bedded to lenticular nodular bioturbated unsorted skeletal wackestone (11th layer in Einasto, 1990, p. 171), which was formed in the restricted shelf facies. (TUG).

The holotype is deposited in the Geological Museum of Tartu University

$$
\begin{aligned}
& \text { Genus Megalomoidea Cox, } 1964 \\
& \text { Megalomoidea walliseri n. sp. } \\
& \text { Pl. I, figs. 1-2; Pl. II, fig. } 1
\end{aligned}
$$

Holotype. Well preserved left valve of the shell, TUG 110/1, Paadla Stage, Sauvere Beds, Ludlow, Saaremaa Island, Kogula quarry, Estonia. Coll. O. H. Walliser.

Material. A left valve.

\section{PLATE I}

Figs. 1-2. Megalomoidea walliseri n. sp. holotype, Ludlow, Paadla Stage, Sauvere Beds, TUG 110/1. 1 - internal view of the left valve (the valve is turned on the plate). 2 - hinge plate, $\times 2$. 

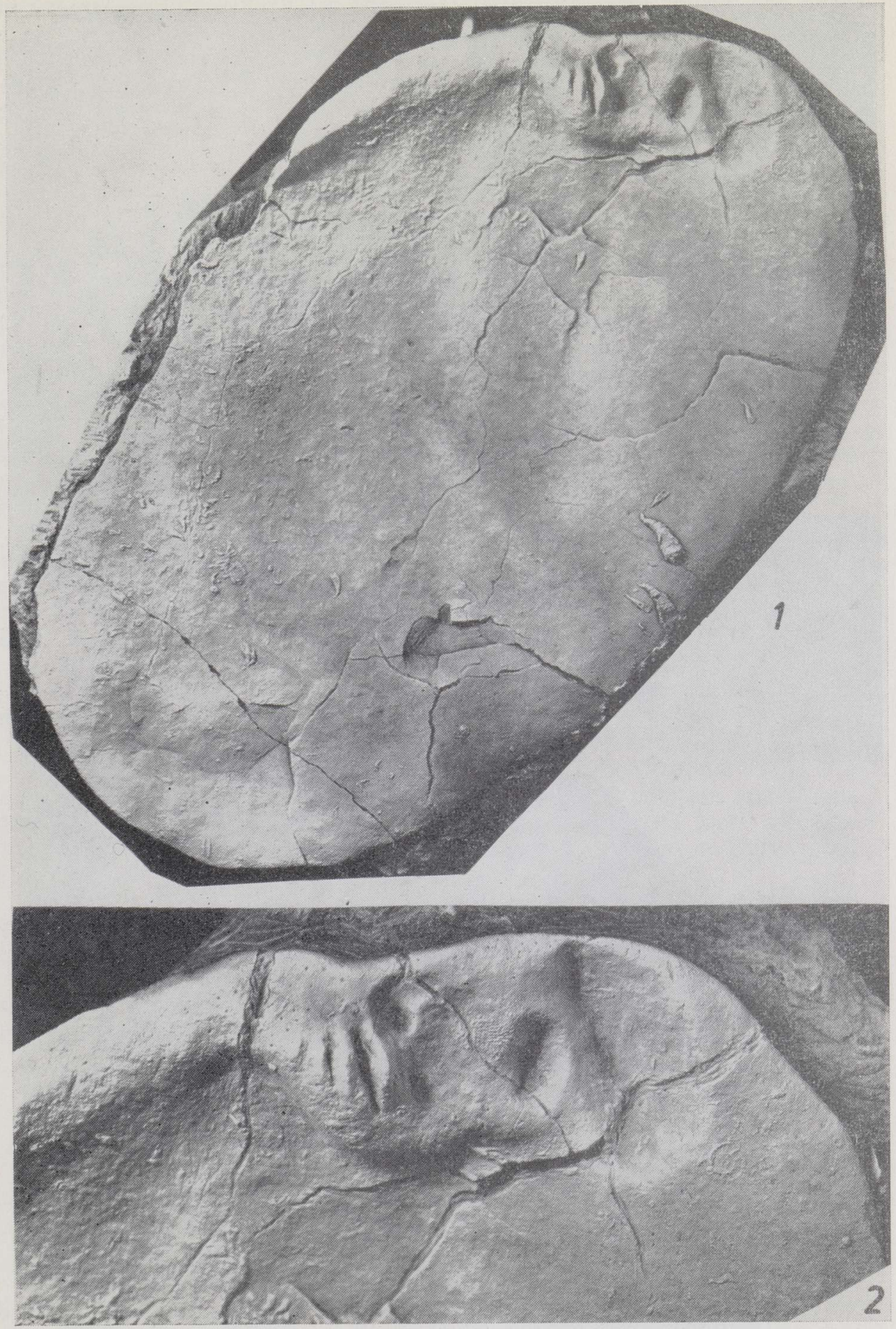

Both specimens are figured in natural size and coated with ammonium chloride before photographing. 

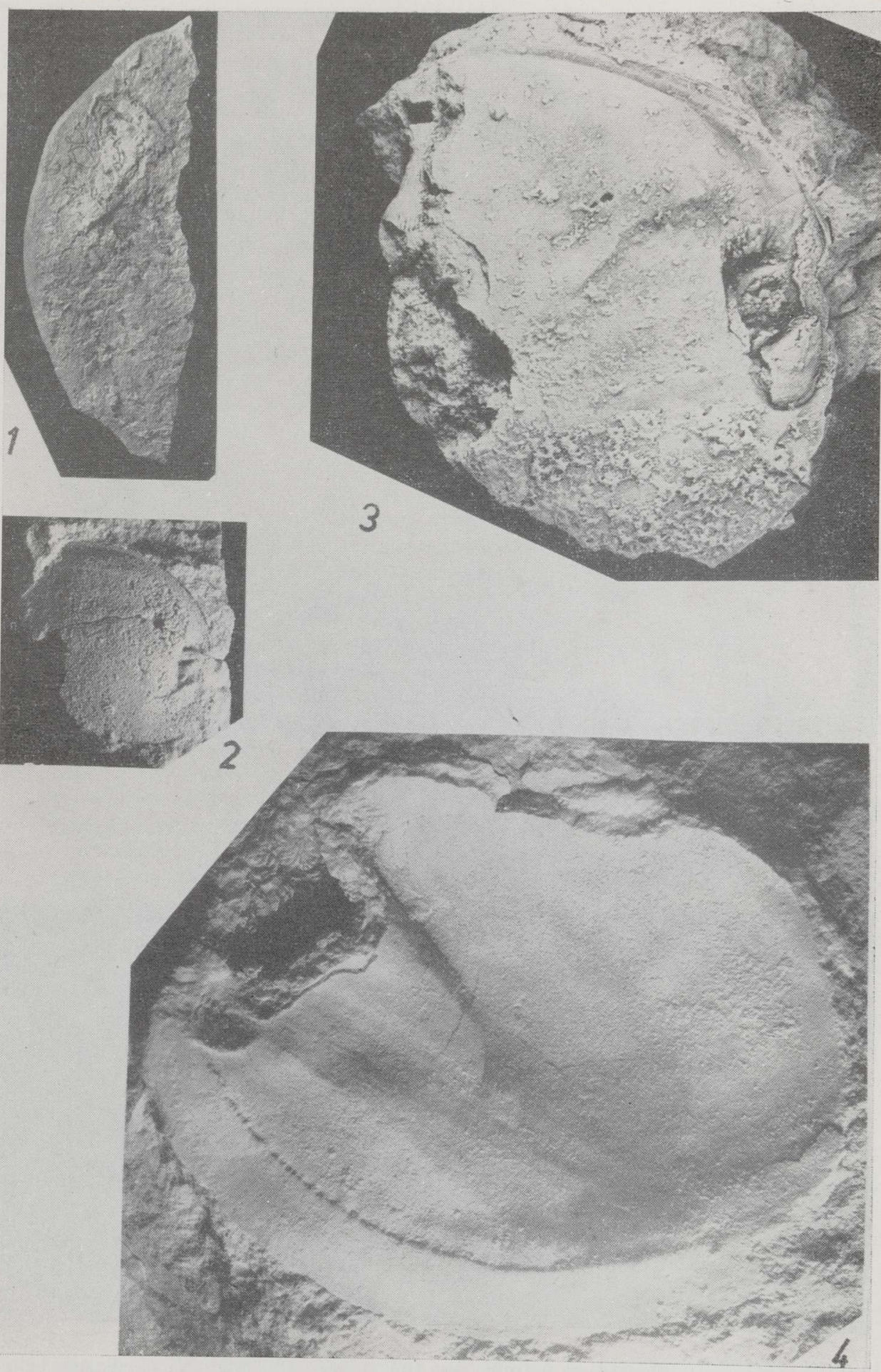

All specimens are figured in natural size and coated with ammonium chloride before photographing. 
Diagnosis. Megalomoidea with relatively large and thin, longitudinally elongated shell. The beak small, prosogyrate, not terminal. Weakly convex. The depression under beak (in the cast) is unnoticeable. Below the beak (on the hinge plate) there are four nearly parallel cardinal teeth. Anterior adductor scar elongated and deeply impressed. Directly above it there is a small oval pedal scar. Another one is near the lower tooth.

Description. Shell large, longitudinally elongated, relatively thin (2$3 \mathrm{~mm}$ ). At hinge region and near the beak the shell is thickened (5$5.5 \mathrm{~mm})$. The valve moderately convex, with the greatest convexity in the $1 / 4$ anterior end and about $1 / 2$ of height of the shell.

Very gently sloping and rather narrow diagonal ridge running obliquely from the centre of the beak to half of the length. The beak is relatively small, prosogyrous, weakly incurved at the anterior end, situated about 0.13 length from the anterior end. Below the beak there are four nearly parallel cardinal teeth; two lower ones are longer and more prominent.

Anterior adductor scar $(17 \times 8 \mathrm{~mm})$ deep, elongated, oblique, more abrupt side turned toward the beak (Pl. I, fig. 2). Underneath this a small $(6 \times 3 \mathrm{~mm})$, deep, elongated pedal scar is situated. Another one $(5 \times 2 \mathrm{~mm})$, likewise oval and deep, lies near the lower tooth. Posterior adductor scar and pallial line unnoticeable. Ligament area weakly curved (maximum width $5 \mathrm{~mm}$ ). The sculpture of the shell is not preserved (Pl. II, fig. 1).

Dimensions of specimen: length $138 \mathrm{~mm}$, height $85 \mathrm{~mm}$, the greatest diagonal $125 \mathrm{~mm}$, breadth $11 \mathrm{~mm}$.

Comparison. The closest species to $M$. walliseri is Megalomus gotlandicus Angelin (Lindström, 1880, p. 18, pl. 19, figs. 1, 2) from Slite or Hemse Beds, Gotland, Sweden. They have similar measures and the shape of the shell, but $M$. gotlandicus has a strong pallial line, more massive beak, different hinge and muscular scars, and its diagonal (umbonal) ridge is unnoticeable.

Estonian Silurian Megalomoidea sp. (Киселев, Синицына et al., 1990, p. 28, Pl. VII, fig. 7) from Rootsiküla Stage has a more rounded anterior margin, small umbo, its diagonal ridge has a different position and shape, ligamental area is narrower, and anterior adductor scar is more globose. Hinge and pedal muscular scars of Megalomoidea sp. have not preserved (Pl. II, fig. 3).

Undescribed Megalomoidea sp. 1 (Jaagarahu Stage, Maasi Beds, Estonia) has a more rounded outline, a strong pallial line, rounded and deep anterior adductor scar, and remarkable anterior crest (Pl. II, fig. 4).

Small (young) Megalomoidea sp. 2 (Jaagarahu Stage, Maasi Beds, Estonia) has a rounded shell and two cardinal teeth (Pl. II, fig. 2).

Occurrence. Ludlow, Paadla Stage, Sauvere Beds, Estonia.

\section{PLATE II}

Fig. 1. Megalomoidea walliseri n. sp. holotype, external view of the fragment. Fig. 2. Megalomoidea sp. 2. Wenlock, Jaagarahu Stage, Maasi Beds, TUG 110/2, internal mould of right valve, old Tuiu quarry. Fig. 3. Megalomoidea sp. Wenlock, Rootsiküla Stage, No. 297/217 (collection of the Department of Historical Geology, St. Petersburg University), internal mould of right valve, old Pamma quarry. Fig. 4. Megalomoidea sp. 1. Horizon and locality the same as in fig. 2, TUG $110 / 3$, internal view of the right valve. 


\section{ACKNOWLEDGEMENTS}

We are grateful to Dr. D. Kaljo and Dr. R. Einasto for their criticism of the text; and to Mr. B. G. Pogrebov for the photos (Pl. I, Pl. II, figs. 1 and 3 ).

\section{REFERENCES}

Einasto, R. 1990. Kogula quarry. - In: Institute of Geology, Estonian Academy of Sciences, IUGS Subcommission on Ordovician Stratigraphy, IUGS Subcommission on Silurian Stratigraphy, IGCP Project "Global Bioevents". Field meeting Estonia 1990. An excursion guidebook. Kaljo, D. and Nestor, H. (eds.). Estonian Academy of Sciences, Tallinn, 170-172.

Lindström, G. 1880. - In: Angelin, N. P. and Lindström, G. Fragmenta Silurica e dono Caroli Henrici Wegelin. - Holmiae, 1-60.

Киселев Г. Н., Синицына И. Н., Исакар М. А., Миронова М. Г., Саладжюс В. Ю. 1990. Атлас моллюсков верхнего ордовика и силура северо-запада ВосточноЕвропейской платформы. Изд-во Ленингр. ун-та, Ленинград, $1-80$.

\section{UUS LIIK MEGALOMOIDEA WALLISERI (BIVALVIA) EESTI SILURIST}

\section{Mare ISAKAR, Irina SINITSONA}

Artiklis on kirjeldatud perekonna Megalomoidea Cox uus liik M. walliseri n. sp. Hästi säilinud karbi vasak poole on leitud Kogula uuest paemurrust (Ludlow).

\section{НОВЫЙ ВИД MEGALOMOIDEA WALLISERI (BIVALVIA) В \\ СИЛУРЕ ЭСТОНИИ}

\section{Маре ИСАҚАР, Ирина СИНИЦЫНА}

Описан новый вид Megalomoidea walliseri из лудлова Эстонни. Левая створка хорошей сохранности была найдена в новой каменоломне Когула (о-в Сааремаа). 